\title{
PENGARUH BERBAGAI ZAT PENGATUR TUMBUH ALAMI DAN ASAL STEK BATANG TERHADAP PERTUMBUHAN VEGETATIF BIBIT MELATI PUTIH (Jasminum sambac (L.) W. Ait.)
}

\section{The Influence of Various Natural Plant Growth Regulator and Origin of Stem Cutting on Vegetative Growth of White Jasmine Jasminum sambac (L) W. Ait.)}

\author{
Indra Lesmana $^{1}$, Dadi Nurdiana ${ }^{2}$ dan Toto Siswancipto ${ }^{2}$ \\ ${ }^{1}$ Mahasiswa Program Study Agroteknologi Fakultas Pertanian Universitas Garut \\ ${ }^{2}$ dosen Fakultas Pertanian Universitas Garut \\ Email: dadi_nurdiana@faperta.uniga.ac.id
}

\begin{abstract}
ABSRAK
Penelitian ini bertujuan untuk mengetahui pengaruh berbagai zat pengatur tumbuh alami dan asal stek batang terhadap pertumbuhan vegetatif bibit melati putih. Penelitian dilaksanakan di Desa Pasawahan Kecamatan Tarogong Kaler Kabupaten Garut dari Bulan Agustus sampai September 2017. Penelitian menggunakan Rancangan Acak Kelompok (RAK) pola faktorial 6 x 3 dan diulang 2 kali. Faktor pertama jenis zat pengatur tumbuh alami (Z) terdiri atas enam taraf, yaitu: $\mathrm{z}_{0}=$ air, $\mathrm{z}_{1}=$ ekstrak bawang merah $100 \%, \mathrm{z}_{2}=$ ekstrak bawang merah $50 \%$, $\mathrm{z}_{3}=$ air kelapa $100 \%, \mathrm{z}_{4}=$ air kelapa $50 \%$ dan $\mathrm{z}_{5}=$ Rootone $\mathrm{F} 100$ ppm. Faktor kedua asal stek batang (B) yang terdiri atas tiga taraf, yaitu: $\mathrm{b}_{1}=$ pangkal batang, $\mathrm{b}_{2}=$ batang tengah dan $b_{3}=$ batang atas. Hasil penelitian menunjukkan tidak terjadi interaksi antara jenis zat pengatur tumbuh dan asal stek batang terhadap pertumbuhan vegetatif tanaman melati. Secara mandiri pengaruh perlakuan zat pengatur tumbuh ekstrak bawang merah dengan konsentrasi $100 \%$ memberikan pengaruh terbaik terhadap luas daun, tinggi tunas, jumlah daun, bobot kering daun, jumlah akar, panjang akar dan bobot kering akar. Asal stek batang tengah secara mandiri memberikan pengaruh terbaik terhadap luas daun, tinggi tunas, jumlah daun dan bobot kering daun. Stek batang pangkal memberikan pengaruh terbaik terhadap jumlah akar, panjang akar dan bobot kering akar.
\end{abstract}

Kata kunci : ZPT, melati, ekstrak bawang merah, air kelapa, stek batang. 


\begin{abstract}
This research was purposed to study the influence of various natural plant growth regulator and origin of stem cutting on vegetative growth of white jasmine. The experiment was conducted in Pasawahan village Tarogong Kaler District of Garut from August until September 2017. This research used Randomized Block Design (RBD) factorial pattern 6 $x 3$ and repeated 2 times. First factor is the type natural plant regulator $(Z)$ consist of six levels, namely: $z_{0}=$ water, $z_{1}=100 \%$ onion extract, $z_{2}=50 \%$ onion extract, $z_{3}=100 \%$ coconut water, $z_{4}=50 \%$ coconut water and $z_{5}=$ Rootone $F 100$ ppm. Second factor is origin of stem cutting $(B)$ consist of three levels, namely; $b_{1}=$ base of stem, $b_{2}=$ middle stem, and $b_{3}=$ upper stem .

The results of this research showed no interaction between the natural plant growth regulator and stem origin on vegetative growth of jasmine plant. Independently the effect of growth regulator treatment with $100 \%$ concentration had the best influence to the leaf area, shoot height, amount of leaves, dry weight of the leaf, amount of root, root length and dry weight of the root. The origin of the middle stem cuttings independently had the best influence to the leaf area, shoot height, amount of leaves and dry weight of the leaf. Stem cuttings had the best influence to the amount of roots, root length and dry weight of the root.
\end{abstract}

Keywords : pant growth regulator, jasmine, onion extract, coconut water, stem cuttings.

\title{
PENDAHULUAN
}

Melati Putih (Jasminum sambac (L.) W. Ait.) merupakan salah satu tanaman hias yang banyak digemari masyarakat Indonesia. Bentuk dan warna bunganya yang putih serta aromanya yang harum menjadi ciri khas dari melati. Tanaman melati banyak dijumpai terutama di daerah tropis mulai dataran rendah sampai dataran tinggi tergantung pada spesies atau jenisnya.

Melati termasuk tanaman hias perdu tegak merambat dan bersifat menahun. Keragaman melati diperkirakan berjumlah kurang lebih 300 spesies (Jones and Reed, 1988). Melati merupakan tanaman asli kepulauan nusantara. Di Indonesia ada tiga spesies melati yang mempunyai potensi untuk dikembangkan yaitu Jasminum sambac Maid of Orleans, Jasminum sambac Grand Duke of Tuscany, dan Jasminum officinale. Pada bulan Juni 1990, bunga melati Jasminum sambac Maid of Orleans dijadikan sebagai "Puspa Bangsa” (Setyawati, 2015).

Melati merupakan salah satu komoditas bernilai ekonomi tinggi, kegunaannya tidak hanya sebagai tanaman hias pot dan taman, tetapi juga sebagai pengharum teh, bahan baku industri parfum, kosmetik, obat tradisional, bunga tabur, penghias ruangan, dan pelengkap dalam upacara adat. 
Produksi bunga melati di Indonesia pada tahun 2013 mencapai 30,26 ribu ton dengan luas areal 979 hektar dan pada tahun 2014 mengalami peningkatan produksi menjadi 36,16 ribu ton dengan luas areal 1569 hektar (BPS dan Dirjen Hortikultura, 2014).

Kebutuhan bibit melati yang semakin meningkat memerlukan perbaikan teknis perbanyakan tanaman yang bersifat cepat dan berproduksi tinggi. Teknis perbanyakan vegetatif terutama dengan stek merupakan salah satu cara yang efisien dan efektif untuk memenuhi kebutuhan bibit melati dalam skala besar dalam waktu yang lebih cepat dan lebih mudah dibandingkan dengan cara cangkok maupun kultur jaringan. Tanaman melati pada umumnya dapat diperbanyak melalui stek, cangkok dan rundukan, namun secara komersial melati diperbanyak dengan stek. Kemampuan stek melati untuk berakar masih sangat rendah sehingga diperlukan adanya perlakuan khusus yaitu dengan pemberian hormon atau zat perangsang tumbuh (ZPT).

Percepatan produksi dengan cara memberi zat pengatur tumbuh saat ini banyak dilakukan dengan kadar tertentu, salah satu zat pengatur tumbuh yang dapat digunakan adalah Rootone-F, ekstrak bawang merah dan air kelapa karena mengandung fitohormon yaitu auksin yang berguna untuk mempercepat serta memperbanyak keluarnya akar-akar baru. Berdasarkan hasil penelitian, ekstrak bawang merah mampu meningkatkan presentase stek tanaman kopi yang hidup sebesar 50\% (Tustiyani, 2017).

Bahan stek batang bisa berasal dari bagian ujung batang dan bisa berasal dari bagian tengah atau pangkal batang, akan tetapi percepatan dalam pertumbuhannya berbeda dikarenakan kandungan auksin yang terdapat di masing-masing bagian tanaman berbeda. Auksin paling banyak terdapat dibagian ujung dari tanaman semakin ke bawah atau semakin jauh dari ujung tanaman maka kandungan auksin semakin berkurang.

Sumber bahan stek yang berasal dari bagian batang yang berbeda mengalami masa perkembangan yang berbeda pula. Keberhasilan stek dalam membentuk akar dipengaruhi oleh umur tanaman, fase pertumbuhan dan perbedaan bagian tanaman yang digunakan sebagai bahan stek. Bagian batang yang digunakan tersebut 
berkaitan dengan kandungan nutrisi didalamnya terutama karbohidrat, protein, lipid, nitrogen, enzim, hormon dan rooting cofactor (Hartmann dan Kester, 1990).

Maksud dari penelitian ini adalah untuk mempelajari pengaruh berbagai ZPT dan asal stek batang terhadap pertumbuhan vegetatif bibit melati. Tujuan dari penelitian ini untuk menentukan ZPT dan asal stek batang terhadap pertumbuhan bibit melati. hipotesis dari penelitian ini adalah Terjadi interaksi antara berbagai zat pengatur tumbuh alami dengan asal stek batang terhadap pertumbuhan vegetatif bibit Melati dan Salah satu zat pengatur tumbuh alami dan asal stek batang akan memberikan pengaruh terbaik terhadap pertumbuhan bibit melati.

\section{METODE PENELITIAN}

\section{Waktu dan Tempat}

Percobaan dilaksanakan di Kampung Babakan Jambe Desa Pasawahan Kecamatan Tarogong Kaler Kabupaten Garut yang terletak pada ketinggian 738 meter di atas permukaan laut. Percobaan ini dilaksanakan pada Bulan Agustus sampai September 2017. Metode penelitian yang digunakan adalah metode eksperimental dengan menggunakan Rancangan Acak Kelompok (RAK) pola faktorial 6 × 3 yang terdiri atas 2 faktor, dengan 2 kali ulangan. Faktor pertama yaitu ZPT alami (Z) terdiri atas 6 taraf. Faktor kedua adalah asal stek batang (B) terdiri atas 3 taraf. Faktor pertama ZPT alami $(\mathrm{Z})$, terdiri atas 6 taraf: $\mathrm{z}_{0}=$ air (kontrol) $\mathrm{z}_{1}=$ Larutan Ekstrak Bawang Merah $100 \% \mathrm{z}_{2}=$ Laruran Ekstrak Bawang Merah 50\% $\mathrm{z}_{3}=$ Air Kelapa $100 \% \mathrm{z}_{4}=$ Air Kelapa 50\% $\mathrm{z}_{5}=$ Larutan rotone-F 100 ppm (pembanding). Faktor kedua asal stek batang (B) terdiri atas 3 taraf, yaitu: $b_{1}$ $=$ Pangkal Batang $\mathrm{b}_{2}=$ Tengah Batang $\mathrm{b}_{3}=$ Ujung Batang

\section{Perlakuan Percobaan}

\section{a. Persiapan Media}

Media yang digunakan untuk pertumbuhan stek yaitu arang sekam yang dimasukan kedalam polybag. Polybag yang telah berisi media diletakkan pada petak percobaan. Media yang telah terisi dalam polybag dibiarkan selama 6 hari 
sebelum ditanami. Hal ini dimaksudkan untuk penyesuaian media terhadap lingkungan.

\section{b. Pengambilan Bahan Stek}

Stek yang digunakan dibagi ke dalam tiga bagian yaitu stek pangkal batang, stek tengah batang dan stek ujung batang. Bagian pangkal stek dipotong miring $\left(45^{\circ}\right)$. Hal ini dimaksudkan untuk memperbesar permukaan penyerapan air dan memberi kesempatan pertumbuhan akar yang seimbang. Bahan stek kemudian direndam dalam larutan Benlate dengan konsentrasi 1 gram/liter selama kurang lebih 10 menit untuk menghindari pertumbuhan jamur.

\section{c. Penyiapan ZPT}

ZPT yang digunakan berasal dari bahan alami yaitu ekstrak bawang merah, air kelapa, Rootone-F (sebagai pembanding) dan air (sebagai kontrol). Ekstrak bawang merah dibuat dengan dua konsentrasi yang berbeda yaitu ekstrak bawang merah $50 \%$ dan $100 \%$.

Pembuatan larutan ekstrak bawang merah dengan konsentrasi $100 \%$ yaitu dengan cara menimbang $1 \mathrm{~kg}$ bawang merah yang selanjutnya dikupas lalu di blender dengan menambahkan air aquades sebanyak 1 liter. Sementara untuk yang konsentrasi $50 \%$ air aquades yang ditambahkan yaitu sebanyak 2 liter.

Pembuatan hormon air kelapa dengan konsentrasi 100\% cukup dengan mengambil air kelapa sebanyak 1 liter sementara untuk konsentrasi 50\% mengambil air kelapa sebanyak 1 liter selanjutnya ditambahkan air aquades sebanyak 1 liter. dan sebagai pembanding menggunakan hormon Rootone-F dengan konsentrasi larutan 100 ppm, dengan cara menlarutkan 100 mg Rootone-F dengan 1 liter air.

\section{d. Pemberian ZPT}

Stek yang sudah dipisahkan berdasarkan bagiannya yaitu stek yang berasal dari pangkal batang, tengah batang dan ujung batang, selanjutnya direndam dalam zat pengatur tumbuh alami setinggi $2 \mathrm{~cm}$ dari pangkal stek selama 12 jam sesuai dengan perlakuan yaitu dengan menggunakan larutan ekstrak bawang merah 
konsentrasi $50 \%$ dan 100\%, air kelapa dengan konsentrasi $50 \%$ dan $100 \%$ dan larutan Rootone-F dengan konsentrasi 100 ppm.

\section{e. Penanaman Stek}

Stek ditanam pada media yang telah disiapkan terlebih dahulu, dibuat lubang agar penanaman stek tidak mengalami kerusakan akibat gesekan dengan media tanam. Setelah diberi zat pengatur tumbuh stek ditanam secara vertikal.

\section{f. Pemeliharaan stek}

Pemeliharaan tanaman meliputi penyiraman, penyulaman, pengendalian hama atau penyakit dan penyiangan gulma. Penyiraman dilakukan 2 kali sehari pada pagi hari dan sore hari untuk mempertahankan kelembaban setiap stek. Penyulaman dilakukan seawal mungkin yaitu pada saat tanaman berumur 1 minggu setelah tanam (MST) terhadap tanaman yang mati, rusak atau terserang hama dan penyakit dengan menggunakan bibit cadangan. Penyiangan gulma dilakukan secara manual, penyiangan dilakukan dengan membersihkan gulma yang ada di area percobaan baik di dalam maupun diluar plot. Pengendalian hama dilakukan pada saat terlihat aktivitas hama pada tanaman.

\section{HASIL DAN PEMBAHASAN}

\section{Jumlah Daun Tanaman (Helai)}

Hasil analisis statistik menunjukkan tidak terjadi interaksi antara berbagai zat pengatur tumbuh dan asal stek batang terhadap jumlah daun tanaman bibit melati putih pada umur 60 HST, tetapi secara mandiri memberikan pengaruh yang nyata. Data pengamatan dapat dilihat pada Lampiran 3. Lebih jelasnya hasil analisis data rata-rata jumlah daun tanaman dapat terlihat pada Tabel 3. 
Tabel 3. Jumlah daun Tanaman

\begin{tabular}{|c|c|}
\hline Perlakuan & Rata-rata Jumlah Daun (helai) \\
\hline $\begin{array}{l}\text { ZPT Alami }(\mathbf{Z}) \\
\mathrm{z}_{0}=\text { air (kontrol) } \\
\mathrm{Z}_{1}=\text { ekstrak bawang merah } 100 \% \\
\mathrm{Z}_{2}=\text { ekstrak bawang merah } 50 \% \\
\mathrm{z}_{3}=\text { air kelapa } 100 \% \\
\mathrm{Z}_{4}=\text { air kelapa } 50 \% \\
\mathrm{Z}_{5}=\text { rootone-F } 100 \mathrm{ppm}\end{array}$ & $\begin{array}{l}4,28 \mathrm{a} \\
9,28 \mathrm{e} \\
8,50 \mathrm{~d} \\
6,45 \mathrm{~b} \\
7,39 \mathrm{c} \\
6,54 \mathrm{~b}\end{array}$ \\
\hline $\begin{array}{l}\text { Asal Stek Batang }(\mathbf{B}) \\
\mathrm{b}_{1}=\text { pangkal batang } \\
\mathrm{b}_{2}=\text { tengah batang } \\
\mathrm{b}_{3}=\text { atas batang }\end{array}$ & $\begin{array}{l}6,99 \mathrm{a} \\
7,34 \mathrm{~b} \\
6,89 \mathrm{a}\end{array}$ \\
\hline
\end{tabular}

Keterangan : Angka rata-rata pada kolom yang diikuti huruf yang sama tidak berbeda nyata pada taraf $5 \%$ berdasarkan Uji Jarak Berganda Duncan.

Angka rata-rata jumlah daun yang tersaji pada Tabel 3 menunjukkan faktor perlakuan $\mathrm{Z}$ yaitu zat pengatur tumbuh menunjukkan semua taraf faktor berbeda nyata kecuali $z_{3}$ dan $z_{5}$. Taraf faktor $z_{1}$ yaitu pemberian zat pengatur tumbuh ekstrak bawang merah dengan konsentrasi $100 \%$ menunjukkan rata-rata jumlah daun lebih banyak dari taraf faktor lainnya. Hal ini menunjukkan bahwa kandungan auksin dalam ekstrak bawang merah $100 \%$ dapat merangsang sel-sel dalam hal ini adalah sel pembentukan daun. Hasil metabolit sekunder dari bawang merah adalah senyawa allin yang segera berubah menjadi senyawa thiosulfinat, seperti allicin, dengan bantuan enzim alliinase (Meutia $d k k$., 2009). Senyawa allicin dengan thiamin (vitamin B1) dapat membentuk ikatan kimia yang disebut allithiamin. Adanya zat tersebut dapat memperlancar metabolisme pada jaringan tumbuhan dan dapat memobilisasi bahan makanan yang ada pada tubuh tumbuhan (Rahayu $d k k$., 2004) sehingga apabila proses metabolisme lancar akan mampu meningkatkan ratarata jumlah daun pada tanaman.

Faktor perlakuan B yaitu asal stek batang menunjukkan taraf faktor $\mathrm{b}_{1}$ tidak berbeda nyata dengan taraf faktor $b_{3}$ tetapi berbeda nyata dengan taraf faktor $b_{2}$. Taraf faktor $b_{2}$ yaitu perlakuan batang tengah menunjukkan rata-rata jumlah daun lebih luas dari taraf faktor perlakuan batang atas dan batang bawah. Hal ini karena 
stek batang yang berasal dari bagian batang tengah memiliki cadangan makanan yaitu karbohidrat yang cukup untuk proses pertumbuhan dan pembentukan daun pada stek. Ketersediaan cadangan makanan pada bahan stek juga dilindungi oleh adanya jaringan epidermis sehingga dapat diafaatkan oleh tanaman untuk proses pembentukan daun. Menurut Suryaningsih (2004) kandungan bahan stek terutama persediaan cadangan makanan seperti karbohidrat dan nitrogen sangat menentukan pertumbuhan akar dan daun pada stek.

\section{Luas Daun Tanaman}

Hasil analisis statistik menunjukkan tidak terjadi interaksi antara berbagai zat pengatur tumbuh dan asal stek batang terhadap luas daun tanaman pada umur 60 HST, tetapi secara mandiri memberikan pengaruh yang nyata. Data pengamatan dapat dilihat pada Lampiran 4. Lebih jelasnya hasil analisis data rata-rata luas daun per tanaman dapat dilihat pada Tabel 4.

Angka rata-rata luas daun yang tersaji pada Tabel 4 menunjukkan faktor perlakuan $\mathrm{Z}$ yaitu zat pengatur tumbuh menunjukkan semua taraf faktor berbeda nyata kecuali taraf faktor $\mathrm{z}_{3}$ dan $\mathrm{z}_{5}$. Taraf faktor $\mathrm{z}_{1}$ yaitu pemberian zat pengatur tumbuh ekstrak bawang merah $100 \%$ menunjukkan rata-rata luas daun paling tinggi dari taraf faktor lainnya. Kondisi tersebut disebabkan oleh adanya hormon seperti sitokinin dan auksin yang terkandung di dalam ekstrak bawang merah yang dapat memacu pertumbuhan daun pada bibit tanaman melati putih. Selain sitokinin dan auksin, ekstrak bawang merah juga mengandung minyak atsiri, sikloaliin, metilaliin, dihidroaliin, flavonglikosida, kuersetin, saponin, peptida, fitohormon, vitamin, dan zat pati dimana semua itu berperan dalam proses metabolisme tanaman (Muswita, 2011). 
Tabel 4. Pengaruh Berbagai Zat Pengatur Tumbuh Alami dan Asal Stek Batang terhadap Luas Daun Tanaman 60 HST

\begin{tabular}{lc}
\hline Perlakuan & Rata-rata Luas Daun $\left(\mathbf{c m}^{\mathbf{2}}\right)$ \\
\hline ZPT Alami $(\mathbf{Z})$ & \\
$\mathrm{Z}_{0}=$ air (kontrol) & $19,77 \mathrm{a}$ \\
$\mathrm{Z}_{1}=$ ekstrak bawang merah 100\% & $49,67 \mathrm{~d}$ \\
$\mathrm{Z}_{2}=$ ekstrak bawang merah 50\% & $39,36 \mathrm{c}$ \\
$\mathrm{Z}_{3}=$ air kelapa 100\% & $29,65 \mathrm{~b}$ \\
$\mathrm{Z}_{4}=$ air kelapa 50\% & $39,51 \mathrm{c}$ \\
$\mathrm{Z}_{5}=$ rootone-F 100 ppm & $29,77 \mathrm{~b}$ \\
\hline Asal Stek Batang $(\mathbf{B})$ & \\
$\mathrm{b}_{1}=$ pangkal batang & $34,12 \mathrm{a}$ \\
$\mathrm{b}_{2}=$ tengah batang & $36,02 \mathrm{~b}$ \\
$\mathrm{~b}_{3}=$ atas batang & $33,73 \mathrm{a}$ \\
\hline
\end{tabular}

Keterangan : Angka rata-rata pada kolom yang diikuti huruf yang sama tidak berbeda nyata pada taraf $5 \%$ berdasarkan Uji Jarak Berganda Duncan.

Faktor perlakuan B yaitu asal stek batang menunjukkan taraf faktor $b_{1}$ tidak berbeda nyata dengan $b_{3}$, tetapi berbeda nyata dengan $b_{2}$. Taraf faktor $b_{2}$ yaitu perlakuan batang tengah menunjukkan rata-rata luas daun tertinggi dari taraf faktor lainnya. Hal ini diduga berkorelasi dengan jumlah daun sejalan dengan banyaknya daun yang terbentuk maka luasan daun juga lebih luas dari taraf faktor lainnya.

\section{Tinggi Tunas (cm)}

Hasil analisis statistik menunjukkan tidak terjadi interaksi antara berbagai zat pengatur tumbuh dan asal stek batang terhadap tinggi tunas bibit melati putih pada umur $60 \mathrm{HST}$, tetapi secara mandiri memberikan pengaruh yang nyata. Data pengamatan dapat dilihat pada Lampiran 5. Lebih jelasnya hasil analisis data ratarata tinggi tunas terlihat pada Tabel 5 .

Angka rata-rata tinggi tunas tanaman yang tersaji pada Tabel 5 menunjukkan faktor perlakuan $\mathrm{Z}$ yaitu zat pengatur tumbuh pada umur 60 HST menunjukkan taraf faktor $\mathrm{z}_{0}$ berbeda nyata dengan taraf faktor lainnya, taraf faktor $\mathrm{Z}_{3}$ tidak berbeda nyata dengan taraf faktor $\mathrm{z}_{5}$ tetapi berbeda nyata dengan taraf faktor $\mathrm{z}_{4}$, dan $\mathrm{z}_{1}$, taraf faktor $\mathrm{z}_{4}$ berbeda dengan taraf faktor $\mathrm{z}_{2}$ dan $\mathrm{z}_{1}$. Taraf faktor $\mathrm{z}_{1}$ yaitu menunjukkan rata-rata tinggi tunas lebih tinggi dibandingkan dengan taraf faktor lainnya. Hal ini diduga karena adanya hormon auksin yang terkandung 
didalam ekstrak bawang merah dengan konsentrasi 100\% dapat merangsang pertumbuhan tunas-tunas baru pada stek.

Tabel 5. Tinggi Tunas 60 HST

\begin{tabular}{lc}
\hline Perlakuan & Rata-rata Tinggi Tunas (cm) \\
\hline ZPT Alami $(\mathbf{Z})$ & \\
$\mathrm{Z}_{0}=$ air (kontrol) & $4,48 \mathrm{a}$ \\
$\mathrm{Z}_{1}=$ ekstrak bawang merah 100\% & $9,98 \mathrm{e}$ \\
$\mathrm{Z}_{2}=$ ekstrak bawang merah 50\% & $8,05 \mathrm{~d}$ \\
$\mathrm{Z}_{3}=$ air kelapa 100\% & $6,70 \mathrm{c}$ \\
$\mathrm{Z}_{4}=$ air kelapa 50\% & $5,80 \mathrm{~b}$ \\
$\mathrm{Z}_{5}=$ rootone-F 100 ppm & $7,37 \mathrm{~cd}$ \\
\hline Asal Stek Batang $(\mathbf{B})$ & \\
$\mathrm{b}_{1}=$ pangkal batang & $7,00 \mathrm{a}$ \\
$\mathrm{b}_{2}=$ tengah batang & $7,48 \mathrm{a}$ \\
$\mathrm{b}_{3}=$ atas batang & $6,71 \mathrm{a}$ \\
\hline
\end{tabular}

Keterangan : Angka rata-rata pada kolom yang diikuti huruf yang sama tidak berbeda nyata pada taraf $5 \%$ berdasarkan Uji Jarak Berganda Duncan.

Faktor perlakuan B yaitu asal stek batang menunjukkan bahwa batang tanaman melati yang diambil dari bagian atas, tengah maupun pangkal tidak berbeda nyata terhadap rata-rata tinggi tunas tanaman. Pertumbuhan tunas pada stek dipengaruhi oleh berbagai faktor yang saling berkaitan seperti bahan stek yang digunakan, lingkungan tumbuh dan perlakuan yang diberikan terhadap bahan stek tersebut (Praswoto et al ., 2006).

\section{d. Bobot Kering Daun per Tanaman (g)}

Hasil analisis statistik menunjukkan tidak terjadi interaksi antara berbagai zat pengatur tumbuh dan asal stek batang terhadap bobot kering daun tanaman pada umur $60 \mathrm{HST}$, tetapi secara mandiri memberikan pengaruh yang nyata. Data pengamatan dapat dilihat pada Lampiran 6. Lebih jelasnya hasil analisis data ratarata bobot kering daun per tanaman dapat dilihat pada Tabel 6 .

Angka rata-rata bobot kering daun yang tersaji pada Tabel 6 menunjukkan faktor perlakuan $\mathrm{Z}$ yaitu zat pengatur tumbuh menunjukkan taraf faktor $\mathrm{z}_{0}$ tidak berbeda nyata dengan taraf faktor $\mathrm{z}_{2}$ dan $\mathrm{z}_{3}$, tetapi berbeda nyata dengan taraf faktor $\mathrm{z}_{5}, \mathrm{z}_{4}$, dan $\mathrm{z}_{1}$, taraf faktor $\mathrm{z}_{5}$ tidak berbeda nyata dengan taraf faktor $\mathrm{z}_{2}$ dan $\mathrm{z}_{3}$, taraf 
faktor $\mathrm{z}_{4}$ tidak berbeda nyata dengan taraf faktor $\mathrm{z}_{1}$ tetapi berbeda nyata dengan taraf faktor $\mathrm{z}_{0}, \mathrm{z}_{2}, \mathrm{z}_{3}$ dan $\mathrm{z}_{5}$. Taraf faktor $\mathrm{z}_{1}$ menunjukkan rata-rata bobot kering daun lebih tinggi dari taraf faktor lainnya. Hal ini karena konsentrasi ekstrak bawang merah $100 \%$ mampu memberi pengaruh terbaik terhadap bobot kering daun. Karena dalam ekstrak bawang merah mengandung fitohormon yang dapat merangsang pertumbuhan daun-daun baru sehingga secara langsung dapat meningkatkan bobot kering daun pada tanaman (Muswita, 2011).

Tabel 6. Bobot Kering Daun Tanaman

\begin{tabular}{lc}
\hline Perlakuan & Rata-rata Bobot Kering Daun $(\mathbf{g})$ \\
\hline ZPT Alami $(\mathbf{Z})$ & \\
$\mathrm{Z}_{0}=$ air (kontrol) & $2.48 \mathrm{a}$ \\
$\mathrm{Z}_{1}=$ ekstrak bawang merah $100 \%$ & $3.96 \mathrm{c}$ \\
$\mathrm{Z}_{2}=$ ekstrak bawang merah $50 \%$ & $2.76 \mathrm{ab}$ \\
$\mathrm{Z}_{3}=$ air kelapa 100\% & $2.80 \mathrm{ab}$ \\
$\mathrm{Z}_{4}=$ air kelapa 50\% & $3.86 \mathrm{c}$ \\
$\mathrm{Z}_{5}=$ rootone-F 100 ppm & $3.12 \mathrm{~b}$ \\
\hline Asal Stek Batang $(\mathbf{B})$ & \\
$\mathrm{b}_{1}=$ pangkal batang & $2,91 \mathrm{a}$ \\
$\mathrm{b}_{2}=$ tengah batang & $3,56 \mathrm{~b}$ \\
$\mathrm{~b}_{3}=$ atas batang & $3,02 \mathrm{ab}$ \\
\hline
\end{tabular}

Keterangan : Angka rata-rata pada kolom yang diikuti huruf yang sama tidak berbeda nyata pada taraf $5 \%$ berdasarkan Uji Jarak Berganda Duncan.

Faktor perlakuan B yaitu asal stek batang menunjukkan taraf faktor $\mathrm{b}_{1}$ tidak berbeda nyata dengan taraf faktor $b_{3}$, tetapi berbeda nyata dengan taraf faktor $b_{2}$. Taraf faktor $b_{2}$ menunjukkan rata-rata bobot kering daun lebih tinggi dari taraf faktor lainnya. Bobot kering daun tanaman juga berkorelasi dengan jumlah daun dan luasan daun sejalan dengan banyaknya daun yang terbentuk serta luasan daun yang lebih luas maka secara otomatis dapat meningkatkan bobot kering daun tanaman. Bobot kering daun tanaman merupakan hasil akumulasi karbohidrat yang pada dasarnya hasil dari kegiatan fotosintesis (Mashudi $d k k ., 2008$ ).

\section{e. Jumlah Akar Tanaman}

Hasil analisis statistik menunjukkan tidak terjadi interaksi antara berbagai zat pengatur tumbuh dan asal stek batang terhadap jumlah akar tanaman bibit melati 
putih pada umur $60 \mathrm{HST}$, tetapi secara mandiri memberikan pengaruh yang nyata. Data pengamatan dapat dilihat pada Lampiran 7. Lebih jelasnya hasil analisis data rata-rata jumlah akar tanaman dapat dilihat pada Tabel 7.

Angka rata-rata jumlah akar yang tersaji pada Tabel 7 menunjukkan faktor perlakuan $\mathrm{Z}$ yaitu zat pengatur tumbuh menunjukkan taraf faktor $\mathrm{z}_{0}$ berbeda nyata dengan taraf faktor lainnya, taraf faktor $\mathrm{z}_{3}$ dan $\mathrm{z}_{5}$ tidak berbeda nyata tetapi berbeda nyata dengan taraf faktor $\mathrm{z}_{2}, \mathrm{z}_{4}$ dan $\mathrm{z}_{1}$, taraf faktor $\mathrm{z}_{2}$ dan $\mathrm{z}_{4}$ tidak berbeda nyata tetapi berbeda nyata dengan taraf faktor $\mathrm{z}_{1}$. Taraf faktor $\mathrm{z}_{1}$ menunjukkan rata-rata jumlah akar yang lebih banyak dari taraf faktor lainnya. Hal ini karena ekstrak bawang merah mengandung auksin (Tustiyani, 2017), hal ini dapat dipahami mengingat fungsi auksin yang mempengaruhi proses fisiologis seperti dalam permeabilitas membran, mendorong pembesaran sel pada batang, mempercepat pembesaran sel akar, dan memperbanyak jumlah akar (Abidin, 1990).

Tabel 7. Jumlah Akar Tanaman 60 HST

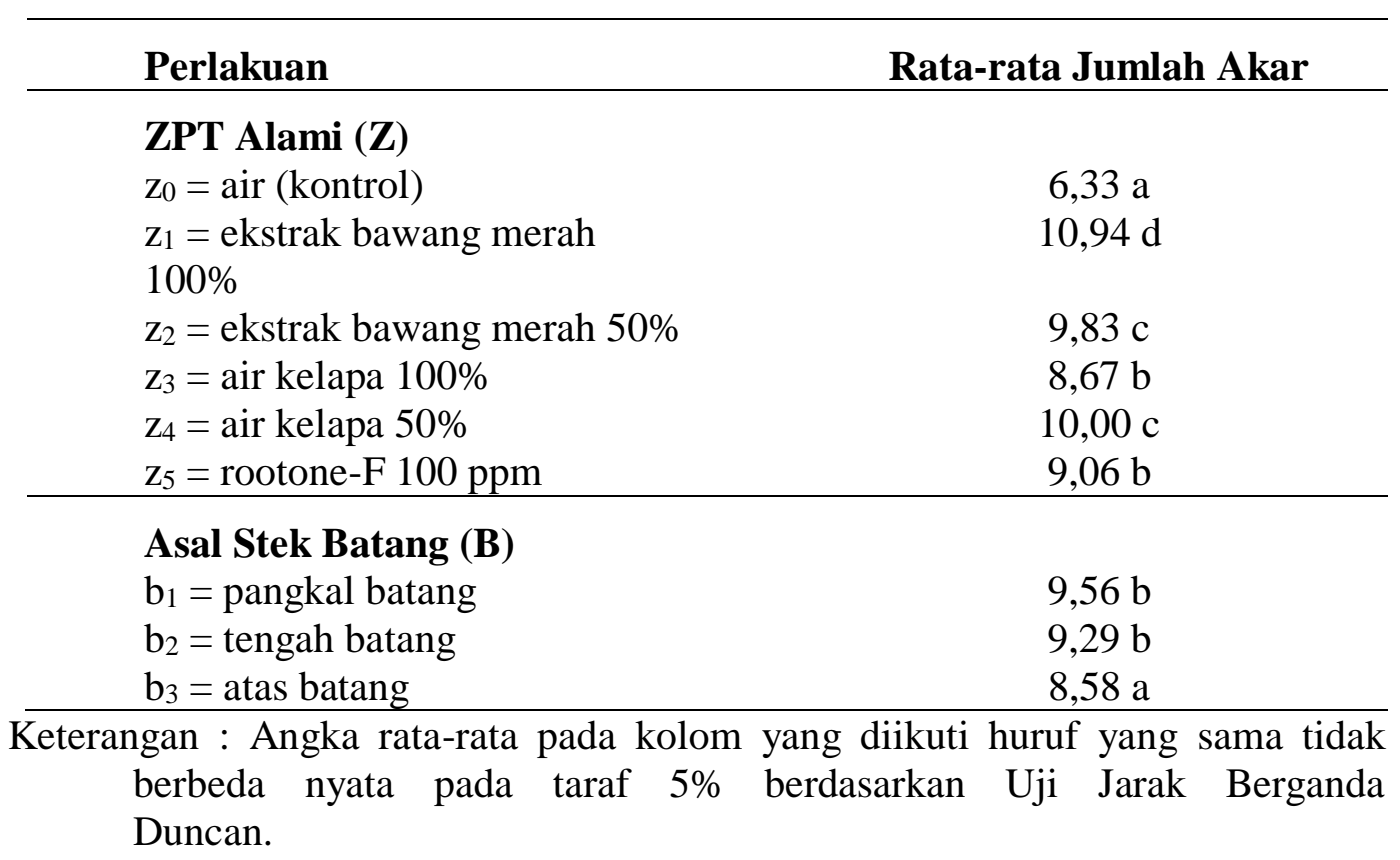

Faktor perlakuan B yaitu asal stek batang menunjukkan taraf faktor $\mathrm{b}_{1}$ tidak berbeda nyata dengan taraf faktor $b_{2}$ tetapi berbeda nyata dengan taraf faktor $b_{3}$, taraf faktor $b_{2}$ berbeda nyata dengan taraf faktor $b_{3}$. Taraf faktor $b_{1}$ yaitu perlakuan pangkal batang menunjukkan rata-rata jumlah akar lebih banyak dari taraf faktor lainnya tetapi secara uji statistik tidak berbenya nyata dengan batang yang berasal 
dari tengah batang. Hal ini karena batang yang berasal dari pangkal batang dan tengah batang memiliki cadangan makanan yaitu karbohidrat yang lebih tinggi dibandingkan dengan batang yang berasal dari bagian atas, dan juga diduga karena adanya jaringan meristem yang ada di dalam batang sehingga mampu menjaga atau melindungi hilangnya air dan zat-zat makanan yang ada pada batang, cadangan makanan pada bahan stek dibutuhkan untuk pembentukan akar yang merupakan indikator keberhasilan tumbuh dalam penyetekan. Kandungan bahan stek terutama persediaan karbohidrat dan nitrogen sangat menentukan pertumbuhan akar pada stek (Suryaningsih, 2004).

\section{f. Panjang Akar Tanaman}

Hasil analisis statistik menunjukkan tidak terjadi interaksi antara berbagai zat pengatur tumbuh dan asal stek batang terhadap panjang akar tanaman bibit melati putih pada umur 60 HST, tetapi secara mandiri memberikan pengaruh yang nyata. Data pengamatan dapat dilihat pada Lampiran 8. Lebih jelasnya hasil analisis data rata-rata panjang akar tanaman dapat dilihat pada Tabel 8.

Angka rata-rata panjang akar yang tersaji pada Tabel 8 menunjukkan faktor perlakuan $\mathrm{Z}$ yaitu zat pengatur tumbuh menunjukkan taraf faktor $\mathrm{z}_{0}$ berbeda nyata dengan taraf faktor $\mathrm{z}_{1}, \mathrm{Z}_{4}$, tetapi tidak berbeda nyata dengan taraf faktor $\mathrm{z}_{2}, \mathrm{z}_{3}$, dan $\mathrm{z}_{5}$, taraf faktor $z_{4}$ tidak berbeda nyata dengan taraf faktor $z_{2}$, tetapi berbeda nyata dengan taraf faktor $\mathrm{z}_{0}, \mathrm{Z}_{1}, \mathrm{Z}_{3}$ dan $\mathrm{z}_{5}$, taraf faktor $\mathrm{z}_{1}$ berbeda nyata dengan taraf faktor lainnya. Taraf faktor $\mathrm{z}_{1}$ yaitu menunjukkan perlakuan ekstrak bawang dengan konsentrasi $100 \%$ menunjukkan rata-rata panjang akar lebih panjang dibandingkan dengan taraf faktor lainnya. Hal ini karena hormon auksin pada bawang merah dengan konsentrasi 100\% dapat meningkatkan proses pemanjangan sel, dalam hal ini adalah sel akar. Auksin menyebabkan sel penerima dalam tanaman mengeluarkan ion hidrogen ke sekeliling dinding sel yang kemudian akan menurunkan $\mathrm{pH}$ dan mengakibatkan menipisnya dinding sel, dan terjadilah pertumbuhan terkait pemanjangan sel akar (Darojat $d k k$., 2015). 
Tabel 8. Panjang Akar tanaman 60 HST

\begin{tabular}{|c|c|}
\hline Perlakuan & Rata-rata Panjang Akar (cm) \\
\hline \multicolumn{2}{|l|}{ ZPT Alami (Z) } \\
\hline $\mathrm{z}_{0}=\operatorname{air}(\mathrm{kontrol})$ & $7,45 \mathrm{a}$ \\
\hline $\begin{array}{l}\mathrm{z}_{1}=\text { ekstrak bawang merah } \\
100 \%\end{array}$ & $10,61 \mathrm{c}$ \\
\hline $\mathrm{z}_{2}=$ ekstrak bawang merah $50 \%$ & $8,32 \mathrm{ab}$ \\
\hline $\mathrm{z}_{3}=$ air kelapa $100 \%$ & $7,78 \mathrm{a}$ \\
\hline $\mathrm{z}_{4}=$ air kelapa $50 \%$ & $8,89 \mathrm{~b}$ \\
\hline $\mathrm{z}_{5}=$ rootone $-\mathrm{F} 100 \mathrm{ppm}$ & $7,41 \mathrm{a}$ \\
\hline \multicolumn{2}{|l|}{ Asal Stek Batang (B) } \\
\hline $\mathrm{b}_{1}=$ pangkal batang & $9,06 \mathrm{~b}$ \\
\hline $\mathrm{b}_{2}=$ tengah batang & $8,67 \mathrm{~b}$ \\
\hline $\mathrm{b}_{3}=$ atas batang & $7,50 \mathrm{a}$ \\
\hline
\end{tabular}

Keterangan : Angka rata-rata pada kolom yang diikuti huruf yang sama tidak berbeda nyata pada taraf $5 \%$ berdasarkan Uji Jarak Berganda Duncan.

Faktor perlakuan B yaitu asal stek batang menunjukkan taraf faktor $\mathrm{b}_{1}$ berbeda nyata dengan taraf faktor $b_{3}$ tetapi tidak berbeda nyata dengan taraf faktor $b_{2}$, taraf faktor $b_{3}$ berbeda nyata dengan taraf faktor $b_{2}$. Taraf faktor $b_{1}$ yaitu batang yang berasal dari batang bagian pangkal menunjukkan rata-rata panjang akar lebih panjang dari pada batang bagian lainnya tetapi secara statistik tidak berbeda nyata dengan batang yang berasal dari bagian tengah. Hal ini karena stek yang berasal dari pangkal batang dan bagian tengah mengandung karbohidrat yang lebih tinggi dibanding dengan batang atas. Hal ini diperkuat dengan pernyataan Supriyanto dan Prakasa (2011), kemampuan pembentukan akar pada suatu jenis tanaman yang di stek anatara lain dipengaruhi oleh kandungan karbohidrat serta keseimbangan hormon dalam bahan stek.

\section{f. Bobot Kering Akar Tanaman (g)}

Hasil analisis statistik menunjukkan tidak terjadi interaksi antara berbagai zat pengatur tumbuh dan asal stek batang terhadap bobot kering akar tanaman bibit melati putih pada umur 60 HST, tetapi secara mandiri memberikan pengaruh yang nyata. Data pengamatan dapat dilihat pada Lampiran 9. Lebih jelasnya hasil analisis data rata-rata bobot kering akar tanaman dapat dilihat pada Tabel 9. 
Tabel 9. Bobot Kering Akar Tanaman 60 HST

\begin{tabular}{lc} 
Perlakuan & $\begin{array}{c}\text { Rata-rata Bobot Kering } \\
\text { Akar }(\mathbf{g})\end{array}$ \\
ZPT Alami $(\mathbf{Z})$ & \\
Z 0 air $($ kontrol) & $2,72 \mathrm{a}$ \\
$\mathrm{Z}_{1}=$ ekstrak bawang merah & $4,06 \mathrm{c}$ \\
$100 \%$ & \\
$\mathrm{Z}_{2}=$ ekstrak bawang merah & $2,96 \mathrm{a}$ \\
$50 \%$ & \\
$\mathrm{Z}_{3}=$ air kelapa 100\% & $2,88 \mathrm{a}$ \\
$\mathrm{Z}_{4}=$ air kelapa 50\% & $3,94 \mathrm{c}$ \\
$\mathrm{Z}_{5}=$ rootone-F 100 ppm & $3,32 \mathrm{~b}$ \\
\hline Asal Stek Batang $(\mathbf{B})$ & \\
$\mathrm{b}_{1}=$ pangkal batang & $3,71 \mathrm{~b}$ \\
$\mathrm{~b}_{2}=$ tengah batang & $3,22 \mathrm{a}$ \\
$\mathrm{b}_{3}=$ atas batang & $3,01 \mathrm{a}$ \\
\hline
\end{tabular}

Keterangan : Angka rata-rata pada kolom yang diikuti huruf yang sama tidak berbeda nyata pada taraf 5\% berdasarkan Uji Jarak Berganda Duncan.

Angka rata-rata bobot kering tanaman yang tersaji pada Tabel 9 menunjukkan faktor perlakuan $\mathrm{Z}$ yaitu zat pengatur tumbuh pada umur $60 \mathrm{HST}$ menunjukkan taraf faktor $\mathrm{z}_{0}$ berbeda nyata dengan taraf faktor $\mathrm{z}_{1}, \mathrm{Z}_{4}$ dan $\mathrm{z}_{5}$, tetapi tidak berbeda nyata dengan taraf faktor $z_{2}$ dan $z_{3}$, taraf faktor $z_{5}$ berbeda nyata dengan taraf faktor $z_{0}, z_{4}$, dan $z_{1}$, tetapi tidak berbeda nyata dengan taraf faktor $z_{2}$ dan $z_{3}$, taraf faktor $z_{4}$ tidak berbeda nyata dengan taraf faktor $z_{1}$, tetapi berbeda nyata dengan taraf faktor $z_{0}, z_{3}, z_{2}$ dan $z_{5}$. Taraf faktor $z_{1}$ yaitu perlakuan zat pengatur tumbuh ekstrak baawang merah dengan konsentrasi $100 \%$ menunjukkan rata-rata bobot kering akar paling tinggi dibandingkan dengan taraf faktor lainnya.

Hal ini karena ekstrak bawang merah dengan konsentrasi $100 \%$ mengandung zat pengatur tumbuh auksin untuk merangsang pertumbuhan akar dan vitamin B1 (thiamin) berperan dalam proses perombakan karbohidrat menjadi energi dalam metabolisme tanaman. Dalam proses inisiasi akar, tanaman memerlukan energi berupa glukosa, nitrogen, dan senyawa lain dalam jumlah yang cukup untuk mempercepat pertumbuhan akar (Hartmann et al., 1997). Dengan demikian proses metabolisme dan inisiasi pada akar berlangsung dengan lancar secara langsung dapat mempengaruhi bobot kering akar tanaman. 
Faktor perlakuan B yaitu asal stek batang menunjukkan taraf faktor $\mathrm{b}_{2}$ tidak berbeda nyata dengan taraf faktor $b_{3}$ tetapi berbeda nyata dengan taraf faktor $b_{1}$. Taraf faktor $b_{1}$ yaitu perlakuan pangkal batang menunjukkan rata-rata bobot kering akar paling tinggi dibandingkan dengan taraf faktor lainnya. Hal ini diduga bahwabobot kering akar tanaman berkorelasi dengan jumlah akar dan panjang akar pada tanaman, sejalan dengan hal tersebut maka secara langsung dapat berpengaruh terhadap bobot kering akar.

\section{Pengamatan Penunjang}

Berdasarkan kriteria Schmidt dan Ferguson (1951), tipe curah hujan di lokasi percobaan berdasarkan data curah hujan 10 tahun terakhir termasuk tipe $\mathrm{C}$ yaitu agak basah, keadaan tersebut mendukung untuk proses pertumbuhan bibit melati. Gulma yang tumbuh di sekitar tanaman percobaan diantaranya yaitu teki (Cyperus rotundus L). Pengendalian dilakukan dengan cara fisik yaitu menyiangi atau mencabut gulma tersebut dengan menggunakan tangan. Penyiangan dilakukan setiap 1 minggu sekali atau bergantung keadaan.

Pengamatan terhadap hama dan penyakit yang menyerang tanaman melati dilaksanakan selama percobaan berlangsung. Hasilnya tidak ditemukan serangan hama dan penyakit tanaman yang berarti, sehingga tidak perlu dilakukan pengendalian.

\section{KESIMPULAN}

Berdasarkan penelitian pengaruh berbagai zat pengatur tumbuh alami dan asal stek batang terhadap pertumbuhan vegetatif bibit melati putih (Jasminum sambac (L.) W. Ait.) dapat disimpulkan :

1. Tidak terjadi interaksi antara berbagai zat pengatur tumbuh alami dan asal stek batang terhadap luas daun tanaman, jumlah daun tanaman, bobot kering daun tanaman, jumlah akar tanaman, panjang akar tanaman dan bobot kering akar tanaman.

2. Secara mandiri perlakuan zat pengatur tumbuh alami yaitu ekstrak bawang merah konsentrasi $100 \%$ berpengaruh paling baik terhadap luas daun, tinggi tunas, jumlah daun, bobot kering, jumlah akar, panjang akar dan bobot kering akar. Penggunaan stek yang berasal dari tengah batang secara mandiri 
berpengaruh paling baik terhadap luas daun tanaman, jumlah daun tanaman, dan bobot kering daun tanaman. Sementara stek batang yang berasal dari pangkal batang berpengaruh paling baik terhadap jumlah akar, panjang akar dan bobot kering akar.

\section{SARAN}

1. Disarankan untuk memperoleh pertumbuhan vegetatif bibit melati yang maksimal menggunakan ZPT alami yaitu ekstrak bawang merah dengan konsentrasi $100 \%$.

2. Perlu dilakukan penelitian lebih lanjut dengan tanah serta lingkungan yang berbeda untuk memastikan pengaruh penggunaan zat pengatur tumbuh alami dan asal stek batang yang terbaik.

\section{DAFTAR PUSTAKA}

Abidin, Z. 1990. Dasar-Dasar Pengetahuan tentang Zat Pengatur Tumbuh. Angkasa, Bandung.

Arinasa, I. B. K., Sujarwo, W. dan Peneng I. N. 2015. The Effect of Rootone-F Concentrations and Type of Culm Cuttings on Growth of Black Petung bamboo (Dendrocalamus asper (Schult.) Backer ex Heyne cv. Black). Bamboo Journal, Japan Bamboo Society, 29: 1-9.

Badan Pusat Statistik dan Direktorat Jenderal Hortikultura. 2014. Produksi Tanaman Melati di Indonesia. BPS dan Direktorat Jenderal Hortikultura, Jakarta.

Bey, Y., Syafii W. dan Sutrisna. 2006. Pengaruh Giberelin dan Air Kelapa terhadap Perkecambahan Anggrek Bulan. J. Biogenesis, 2 (2): 41-6.

Darojat, M. K., R. S. Resmisari dan A. Nasichuddin. 2015. Pengaruh Konsentrasi dan Lama Perendaman Ekstrak Bawang Merah (Allium cepa L.) terhadap Viabilitas Benih Kakao (Theobroma cacao L.). Jurnal Penelitian Universitas Islam Negeri Maulana Malik Ibrahim, Malang.

Elisabeth, M. H. 2004. Pengaruh Rootone-F dan Ukuran Diameter Stek terhadap Pertumbuhan Dapa Batang Jati (Tectona grandis L. F.). Skripsi. Jurusan Kehutanan Fakultas Pertanian, Universitas Pattimura.

Gardner, F. P., Brent. P. R and Roger L. M. 1991. Fisiologi Tanaman Budidaya. Penerjemah Herawati Susilo dan Pendamping Subiyanto. Universitas Indonesia Press, Jakarta.

Hartmann, H. T. and D. E. Kester. 1990. Plant Propagation: Principles and Practices Fifth Edition. Prentice Hall. International Inc, New York. 
Hartmann, H. T., D.E. Kester, F. T. Davies, dan R. L. Geneve. 1997. Plant Propagation (6th Edition). Upper Saddle River. New Jersey.

Heddy, 1991. Hormon Tumbuh. CV. Rajawali, Jakarta.

Kasijadi, F., Purbiati T., Mahfudi M. C., Sudaryono T. dan Soemarsono S. R. 1999. Teknologi Pembibitan Salak secara Cangkok. J. Hort, 9 (1): 1-7.

Kosasih, A. S. dan Rochayat N. 2000. Pengaruh Pemberian ZPT terhadap Keberhasilan Perbanyakan Jamuju (Podocarpus imbricata). Buletin Penelitian Hutan, 619: 1-11.

Kramer and Kozlosky. 1960. Physiology of Trees. Mc Graw Hill Book Co, New York.

Kusumo, 1984. Zat Pengatur Tumbuh. CV Yasaguna, Jakarta.

Lewerissa, E. Penggaruh Penggunaan Rootone-F terhadap Pertumbuhan Stek Pucuk Tanaman Meranti Putih (Shorea asamica, Dyer) dan Meranti Merah (Shorea selanica, B. L.) pada Kebun Pangkas PT. MANGTIP UNID II. Skripsi. Jurusan Kehutanan Fakultas Pertanian, Universitas Pattimura.

Mashudi, D. Setiadi, dan A. F Ariani. 2008. Pertumbuhan Tunas Tanaman Pulai pada Beberapa Tinggi Pangkasan dan Dosis Pupuk NPK. Jurnal Pemuliaan Tanaman, 2 (2): 1-9.

Meutia, A. Yustikawati dan Nisa M. 2009. Kolaborasi Tempe dan Bawang Putih. Jurnal Hortikultura, Bogor.

Muswita. 2011. Pengaruh Konsentrasi Bawang Merah (lium cepa 1.) terhadap Pertumbuhan Setek Gaharu (Aquilaria malaccencis $O K E N)$. Jurnal Penelitian Universitas Jambi, 5 (1): 16-22.

Ningsih, E. M. N., Nugroho, Y. A. dan Trianitasari. 2010. Pertumbuhan Setek Nilam (Pogostemon Cablin Benth.) pada berbagai Komposisi Media Tumbuh dan Dosis Penyiraman Limbah Air Kelapa. Agrika, 4 (1): 37-47.

Praswoto, N.H., J.M. Roshetko dan G.E.S.Manurung. 2006. Tehnik Pembibitan Dan Perbanyakan Vegetatif Tanaman Buah. World Agroforestry Centre (ICRAF) dan Winrock Internasional. Bogor.

Rahayu E, Dan Berlian N, 2004. Mengenal Varietas Unggul dan Cara Bududaya Secara Kontinyu Bawang Merah. PT Penebar Swadaya, Jakarta.

Schmidt, F. H. and Ferguson. 1951. Rain Fall Types Basedand Wet and Dry Periode Ratios for Indonesian. With Western New Guinea. Kementrian Perhubungan Djawatan Metreologi dan Geofisika, Jakarta.

Rismawati dan Syakhril. 2013. Respons Asal Bahan Stek Sirih Merah (Piper crocatum Ruiz and Pav.) terhadap Konsentrasi Rootone-F. Diakses dari http://ejurnal.untag-smd.ac.id/index.php/AG/article/download/114/180.

Rukmana, R. 1997. Usaha Tani Melati. Kanisius, Yogyakarta.

Setyawati. 2015. Budidaya Tanaman Melati. Balai Penelitian Tanaman Hias Cianjur Iptek Hortikultura, (1): 1-4. 
Sudaryono, T. dan Soleh M. 1994. Induksi Akar pada Perbanyakan Salak Secara Vegetatif. Jurnal Penelitian Hortikultura, 6 (2): 1-12.

Sudomo, S., Pudjiono dan M. Na'iem. 2007. Pengaruh Mata Tunas terhadap Kemampuan Hidup dan Pertumbuhan Stek Empat Jenis Hibrid Murbei. Jurnal Pemuliaan Tanaman Hutan, 1(1):1-11.

Supriyanto dan K. E. Prakasa. 2011. Pengaruh Zat Pengatur Tumbuh Rootone-F terhadap Pertumbuhan Stek Duabanga mollucana Blume. Jurnal Silvikultur Tropika, 3 (1): 59-65.

Suryaningsih. 2004. Pengaruh Jenis Zat Pengatur Tumbuh dan Media Tanam terhadap Pertumbuhan Stek Lada (Piper nigrum L.). Skripsi. UNS Press, Surakarta.

Suryowinoto, S. M. 1997. Flora Eksotika Tanaman Hias Berbunga. Kanisius, Yogyakarta.

Tjitrosoepomo, G. 2000. Taksonomi Tumbuhan (Spermatophyte). UGM Press, Yogyakarta

Tustiyani, I. 2017. Pengaruh Pemberian Berbagai Zat Pengatur Tumbuh Alami Terhadap Pertumbuhan Stek Kopi. Jurnal Pertanian 8 (1) : 46-50.

Warsa, T. dan Cucu S. A. 1982. Teknik Perancangan Percobaan Percobaan Serial Pengenalan Dasar Statistika Terapan. Universitas Padjadjaran, Bandung.

Wudianto. 1998. Membuat Stek Cangkok dan Okulasi. PT. Penebar Swadaya, Jakarta.

Yasman dan Smits. 1998. Metode Pembuatan Stek Dipterocarpaseae. Badan Penelitian dan Penembangan Kehutanan. Balai Penelitian Kehutanan, Samarinda.

Zuryanisa. 2006. Pengaruh Waktu Dan Persentase Pemangkasan Tunas terhadap Pertumbuhan Vegetatif Dan Produksi Buah. Jurnal Hortikultura, 4 (2):1620 